\title{
Intercultural Dialogue in the Middle Ages: A Christian Cemetery in Pagan Vilnius
}

\author{
By Rytis Jonaitis*
}

\begin{abstract}
In Medieval Europe, Lithuania remained a pagan state the longest, officially accepting Catholic baptism only in 1387. But the country had already been influenced by Christian culture, Orthodox from the East and Catholic from the West, since the 11th century. It should be noted that this influence was not the same: Catholicism was mostly brought 'by fire and sword' in the role of the Teutonic Order while the spread of Orthodox Christianity could be more peaceful. It is frequently stressed that the Ruthenian Orthodox Christians were close neighbours of the pagan Lithuanians, settling in Lithuania as subjects of the grand dukes. While the Catholics needed to be invited, the Orthodox Christians from the Ruthenian lands were already subjects of the grand dukes. Thus, communities of both branches of Christianity: Eastern Orthodox and Western Catholic, had settled here and were interacting in a still pagan environment in pagan cities ruled by pagan dukes. This article, in seeking to present the circumstances of the settlement of one of the early Christian communities in Vilnius, the Orthodox one, and its development, examines this community through data from the burial site it left and the interpretation of those data.
\end{abstract}

\section{Introduction}

The Chronica nova Pruthenica (New Prussian Chronicle) ${ }^{1}$ of Wigand of Marburg contains the following entry describing the events of September 1383: "The Master sent forward four commanders, namely Elbing, Balga, Brandenburg, and Christburg with orders to burn the Ruthenian city as much as they were able. And a battle occurred there on the bridge." ${ }^{2}$ In this way this part of the city of Vilnius, the Civitas Ruthenica or Ruthenian city is mentioned for the first time in written sources. Lithuania was still a pagan country at that time and therefore the question arises as to why and how representatives of the Orthodox Christian church had settled in Vilnius, in the part of the city mentioned by the Western European chronicler.

"Research Fellow, Lithuanian Institute of History, Lithuania.

1. Chronica nova Prutenica (New Prussian Chronicle) is one of the main sources about the history of the Prussian lands and parts of the Grand Duchy of Lithuania, covering the period between 1293 and 1394 .

2. In the Latin: exercitus festinat prope William et premisit magister 4 commendatores, sc. de Elbingo, de Balga, de Brandenburg et Kirstburg, ut civitatem Ruthenicam incinerarent modo quo possent, et fit ibidem conflictus in ponte. Vygandas Marburgietis, Naujoji Prūsijos Kronika (Vilnius: Vaga, 1999), 186. 
In Medieval Europe, Lithuania remained a pagan state the longest, officially accepting Catholic baptism only in 1387. But the country had already been influenced by Christian culture, Orthodox from the East and Catholic from the West, since the $11^{\text {th }}$ century. It should be noted that this influence was not the same: Catholicism was mostly brought "by fire and sword" in the role of the Teutonic Order while the spread of Orthodox Christianity could be more peaceful as many of the Ruthenian lands already in the time of King Mindaugas (12531263), were under the influence of the Grand Duchy of Lithuania. ${ }^{3}$ Conditions arose for the first Christian communities to settle in pagan cities in a pagan state, which was founding cities in the second half of the $13^{\text {th }}$ century. That migration was not spontaneous. Could Christians have freely settled in a pagan city in a pagan environment? The arrival of Christian communities must have been initiated by the grand dukes; the new state needed trained craftsmen and merchants. The archaeological sources together with the historical context show that the beginning of the founding of the first cities likely coincided with the reign of Grand Duke Traidenis of Lithuania (1268-1282). Lithuania's grand dukes, beginning with Traidenis, understanding the importance of Christian immigrants for the economic and commercial situation of the cities, invited them to the new city of Vilnius.

In fact, although some residents were Christian, the history of the Orthodox and Catholic Christian communities was not identical in Lithuania. ${ }^{4}$ First of all, the view of the representatives of the different religions was shaped at that time by the contemporary political situation, i.e. the relationship between Lithuania and its neighbors. In speaking about pagan Lithuania, it is frequently stressed that the Ruthenian Orthodox Christians were close neighbors of the pagan Lithuanians, settling in Lithuania as subjects of the grand dukes. While the Catholics needed to be invited, ${ }^{5}$ the Orthodox Christians from the Ruthenian lands were already subjects of the grand dukes, his wife even being one of them. In addition, the grand duke was the guarantor of their safety in a pagan environment. Thus, communities of both branches of Christianity: Eastern Orthodox and Western Catholic, had settled here and were interacting in a still pagan environment in pagan cities ruled by pagan dukes.

3. Edvardas Gudavičius, Lietuvos Istorija nuo Seniausių laiku iki 1569 Metu (Vilnius: Mokslas, 1999), 48.

4. Ритис Йонайтис and Ирма, Каплунайте, "Многокультурный Вильнюс. Сосуществование двух христианских конфессий на раннем этапе развития города," Elite ou egalite. Севернал Русь и культурные трансформации в Европе VII-XII вв. (2017): 283-304.

5. Rowell C. Stephen (Ed.), Gedimino Laiškai. Chartularium Lithuaniae res Gestas Magni ducis Gedeminne Illustrans (Vilnius: Vaga, 2003). The so called Gedimino laiškai or the letters of Gediminas were written in 1323-1324 by Grand Duke of Lithuania Gediminas. These letters are the oldest documents about Vilnius. They were sent to Western Europe, the pope, merchants, and craftspeople. 
Lithuania's second half of the $13^{\text {th }}-14^{\text {th }}$-century political history has been fairly thoroughly investigated in historiography. But the main focus has been on the East-West policies of the grand dukes, the battles with the Order, and changes in the country's domestic political history. ${ }^{6}$ This area of interests was in large part determined by the nature of the contemporary written sources (and especially their lack). In speaking specifically about Christian immigrants in Vilnius, both Orthodox and Catholic, this topic has not received sufficient attention, from questions of the places of worship ${ }^{7}$ to initial attempts to define the areas inhabited by both communities. ${ }^{8}$ Attention is usually focused on the so-called political history, not on an analysis of the everyday life of the immigrants or, especially, the history of their relationships with each other and with the local pagans. Ordinarily the letters written by Grand Duke Gediminas of Lithuania (when talking about the first Catholics in Vilnius) and the earlier mentioned New Prussian Chronicle of Wigand of Marburg are dissected. Archaeological data is currently allowing for the augmentation of this investigation direction which has mostly been determined by the nature of the historical sources. ${ }^{9}$ The inclusion of precisely these data has provided new knowledge about the relationships among the different communities in Vilnius, allowing the chronology of the settlement of the communities in Vilnius, their locations and the changes to them, and their population density to be determined as well as helping to follow the history of the relationships among the city's residents.

This article, in seeking to present the circumstances of the settlement of one of the early Christian communities in Vilnius, the Orthodox one, and its development, examines this community through data from the burial site it left and the interpretation of those data.

6. Darius Baronas, Artūras Dubonis and Rimvydas Petrauskas, XIII a.-1385 m. Valstybès Iškilimas tarp Rytu ir Vakaru. Lietuvos Istorija, no. III (Vilnius: Baltos Lankos, 2011).

7. Rytis Jonaitis, “Orhodox Churches in the Civitas Rutenica Area of Vilnius: The Question of Location," Archaeologia Baltica, no. 16 (2011): 110-128.

8. For a broader discussion of the historiography of both Christian communities in Vilnius see: Jonaitis, Civitas Rutenica Vilniuje XIII-XV a (Klaipėda: Klaipėdos Universitetas, 2013), 6-15; Irma Kaplūnaite, Vilniaus Miesto Katalikiškoji Dalis XIV-XVI Amžiaus Pradžioje (Klaipèda: Klaipėdos Universitetas, 2015), 12-31.

9. Two dissertations recently prepared by this article's authors investigate the history of the Orthodox and Catholic Christian communities in Vilnius primarily on the basis of archaeological sources: Jonaitis, Civitas Rutenica; Kaplūnaitè, Vilniaus Miesto. 


\section{The First Settlement of Orthodox Christians in Lithuania}

The very first contacts between the pagan Lithuanians and their Orthodox Christian neighbors occurred prior to the state's creation in the $13^{\text {th }}$ century. The relationship with the neighbors was accompanied by military conflicts and peace treaties as well as steady commercial and cultural ties. While for both sides, the foundation of these relations in the $11^{\text {th }}$ century was military conflicts, a stage of peace treaties against common enemies began in the $13^{\text {th }}$ century. ${ }^{10}$ An exchange of captives and perhaps the migration of one or more families to Lithuanian ethnic territory could have occurred at that time, but Lithuania had no need or possibility for a greater movement of people or for the founding of a separate suburb. A new pagan state far from the main trade routes was not attractive to Christian immigrants. In addition, the pagan dukes did not yet feel a great need for such immigrants.

The process of the city's creation, i.e., from the third quarter of the $13^{\text {th }}$ century is associated with a massive influx of Christians. At that time two such administrative centres in ethnic Lithuania were stood out for their multi-religious nature: Kernavė and Vilnius ${ }^{11}$ (Figure 1).

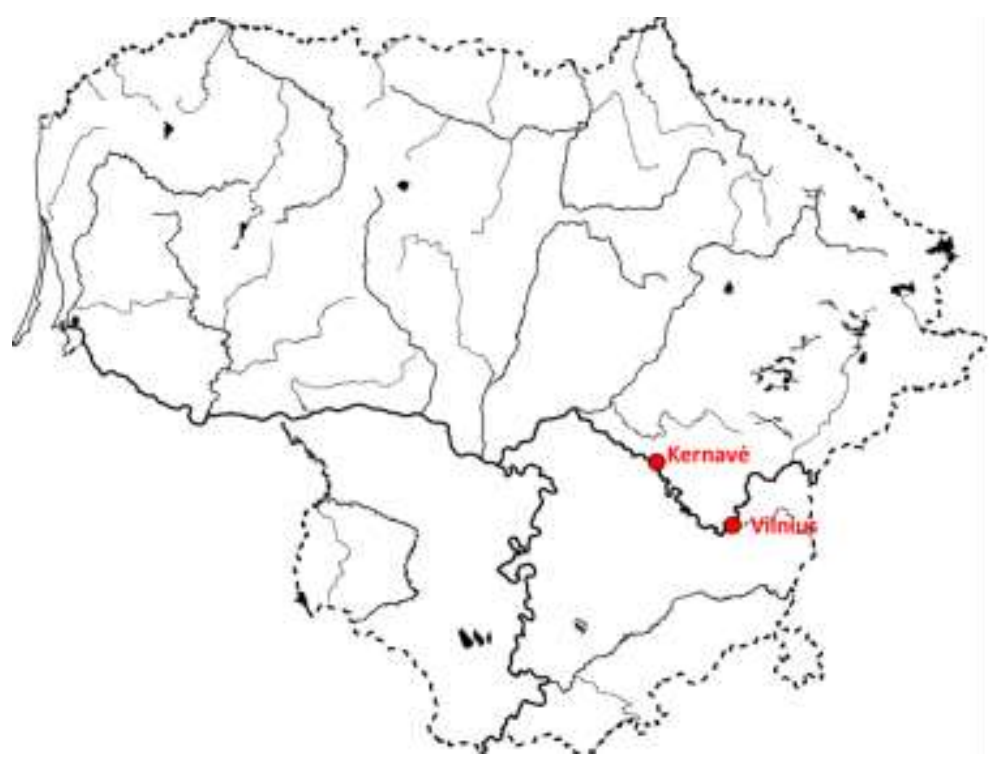

Figure 1. Vilnius and Kernave Location

Source: Lietuvos Archeologijos Draugija. Additions by R. Jonaitis.

10. Vladimiras Pašuta, Lietuvos Valstybès Susidarymas (Vilnius: Mintis, 1971), 212-213; Tomas Baranauskas, Lietuvos Valstybés Ištakos (Vilnius: Vaga, 2000), 177; Laurynas Kurila, "Lietuvių Etninė Riba Rytuose IX-XII a. (2. Rašytinių Šaltinių Duomenys)," Lietuvos Archeologija, no. 28 (2005): 121-132.

11. Gudavičius, Lietuvos, 92. 
Kernavè, which is considered Lithuania's first capital flourished earlier. It was the principal residence and domain of Grand Duke Traidenis. It is likely that the first Orthodox Christian immigrant community was created precisely there in the second half of the $13^{\text {th }}$ century..$^{12}$ But those investigating Kernave do not agree, claiming that the inhumation cemetery there is not the legacy of the Orthodox Christians but of the Yotvingians. ${ }^{13}$ This was probably a community of craftsmen and merchants catering to the grand duke's needs for household and luxury goods. ${ }^{14}$ The Orthodox Christians could have settled there after the influence of Galicia-Volhynia became stronger, strengthening the young Lithuanian state and the ongoing centralization processes.

After the death of Grand Duke Traidenis, ${ }^{15}$ a new dynasty, the Gediminids, entered the Lithuanian political arena. Thus during the reign of Grand Duke Vytenis (1295-1316) a favorable political situation developed for the emergence of a new center, which would replace Kernave, the patrimony of Grand Duke Traidenis. Vilnius, the future capital of the Grand Duchy of Lithuania (and the current capital), became precisely such a center. The history of the creation of an Orthodox Christian community in Vilnius begins from this moment. While it is possible to talk about Orthodox, Catholic, and pagan contacts in the late $13^{\text {th }}$ century, mostly with the ruler's entourage up until then, one needs to talk about the life of two Christian communities together with the pagans and their 'managing to fit' into one city (Figure 2).

12. Jonaitis, Civitas Rutenica, 2013; Artūras Dubonis, "Lietuva po karaliaus Mindaugo Mirties: Kova dèl Sosto 1264-1268 m." Istorijos Akiračiai. Skiriama Profesoriaus, Habilituoto Daktaro Antano Tylos 75-Mečiui (2004): 65-76; Dubonis, Traidenis (Vilnius: Lithuanian Institute of History, 2009); Dubonis, "G. Vèlius. Kernavès Miesto Bendruomenė XIII-XIV a. Vilnius: Vilniaus Universiteto Leidykla, 2005, 112 p.: il. ISBN 9986-19-816-X," Lietuvos Archeologija, no. 35 (2009): 259-264.

13. Aleksiejus Luchtanas and Gintautas Vèlius, "Laidosena Lietuvoje XIII-XIV a," Vidurio Lietuvos Archeologija: Etnokultūriniai Ryšiai (1996): 80-88; Gintautas Vèlius, Kernavès Miesto Bendruomené XIII-XIV Amžiuje (Vilnius: Vilniaus Universitetas, 2005); Гинтаутас, Велюс, “Могильник XIII-XIV вв. В Кярнаве (Кривейкишис): этническая принадлежность погребенных)," Археология и история Аитвы и Северо-Запада России $в$ средневековье (2013): 59-79.

14. Jūrate Kiaupienè and Rimvydas Petrauskas, Nauji Horizontai: Dinastija, Visuomené, Valstybè. Lietuvos Didžioji Kunigaikštystè 1386-1529 m. Lietuvos Istorija, no. IV (Vilnius: Baltos Lankos, 2009), 90.

15. Traidenis died without leaving an heir. 


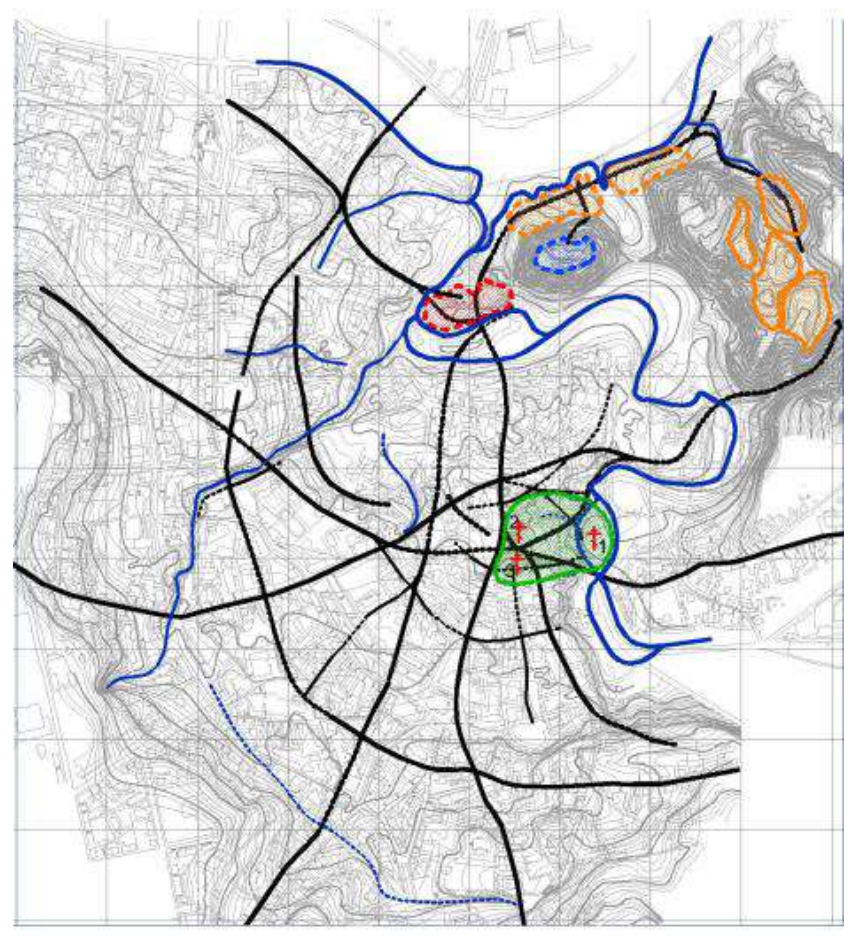

Figure 2. Vilnius Situation in the End of the $13^{\text {th }}$ - The Beginning of the $14^{\text {th }}$ Century. Blue - Citadel; Red - Catholic mission; Green - "Civitas Rutenica" or Ruthenian City; Yellow-Pagans

Source: O. Valionienė. Additions by R. Jonaitis.

The growing city with its grand dukes, who understood the benefits provided by the Christian immigrants, became a magnet for settlers. It is possible to distinguish several reasons for Orthodox Christians to settle in Vilnius. First of all, the residence of the grand dukes and its environs must have been a magnet; the new commercial possibilities would have drawn Orthodox Christian merchants and craftsmen. There would have also been unforeseen circumstances for settling there, such as becoming a captive ${ }^{16}$ or serving in the grand duke's army. For example, the Livonian Rhymed Chronicle (German: Livländische Reimchronik) ${ }^{17}$ mentions the active participation of Ruthenian bowmen in the 1274 siege of Daugavpils. ${ }^{18}$ It is possible to make an assumption that the first representatives of Orthodox Christianity in Vilnius were the warriors mentioned in written sources.

16. Дарюс, Баронас, Древнейшие следы пребывания русских в Вильнюсе," Slavistica Vilnensis. Kalbotyra 53, no. 2 (2004): 163.

17. The so called Livonian Rhymed Chronicle covers the period 1180-1343 and contains information about Livonia - current South Estonia and Latvia.

18. “Eiliuotoji Livonijos Kronika, "Mindaugo Knyga: Istorijos Šaltiniai apie Lietuvos Karaliu" (2005). 
The military comradery in Ruthenia at that time, it can be said, was in the vanguard of protecting Christian values. ${ }^{19}$ Of course, serving in the Lithuanian grand duke's ranks was not an invitation to proselytise but through these people some of the pagans also serving the grand duke could have been introduced to Orthodox Christianity. But warriors were only one societal stratum useful to the new state; skilled craftsmen and merchants were also definitely desirable. In addition, Orthodox Christians could have lived in a pagan city only if a place of worship, i.e., an Orthodox church, was present. There must have been priests in the city. The data in the written sources also reflects their presence. For example, we know of Nestor, who in the mid- $14^{\text {th }}$ century could have performed Orthodox Christian rites among the ruler's entourage and in the city itself. ${ }^{20}$

Next up for discussion is one of the biggest differences in the establishment of the Orthodox and Catholic communities in pagan Vilnius, namely the circumstances under which these communities were created in the city. The Catholics needed to be specially invited, which is reflected in the letters of Grand Duke Gediminas. ${ }^{21}$ In addition, the grand duke not only had to guarantee the immigrants Rìga Law, but also promised to supply warriors and squires with equipment and property, everyone else with land.22 There were far fewer Catholics but they needed the grand duke's aegis and security guarantees. At the same time Lithuania was experiencing a savage military conflict with both branches of the Teutonic Order: Prussian and Livonian, which ended with the 1410 Lithuanian and Polish victory at the Battle of Žalgiris (Grunwald). Meanwhile the Orthodox Christians came to Vilnius without a separate invitation as subjects of the grand duke.23 Other data also shows that they had a large community in Vilnius. For example, as is shown in one source, in 1387 Jogaila, Grand Duke of Lithuania (1377-1401) and King of Poland (1386-1434), baptised "half the residents of Vilnius." ${ }^{24}$ Meanwhile the other half must have already been

19. Евгений Мусин, Milites Christi древней Руси. Воинскал культура русского средневековья в контексте религиозного менталитета (Militaria Antiqua no. VIII.). (Санкт-Петербург: Петербургское востоковедение, 2005), 63.

20. Баронас, “Древнейшие," 162.

21. Gedimino Laiškai, XVII.

22. For more about the circumstances of the settlement of the Catholics, see: Kaplūnaitè, Vilniaus Miesto, 32-41.

23. According to letters during the reign of Grand Duke Gediminas (1316-1341), part of the Ruthenian cities and lands: Vitebsk, Volyn, Polotsk, etc. fell into the Lithuanian sphere of influence. For more see: Stephen, C., Rowell, Iš Viduramžiu Ūku Kylanti Lietuva (Vilnius: Baltos lankos, 2001), 89-93.

24. Juozas Jurginis, Vytautas Merkys and Adolfas Tautavičius, Vilniaus Miesto Istorija. Nuo Seniausiu Laiku iki Spalio Revoliucijos (Vilnius: Mintis, 1968), 49. 
Christians, ${ }^{25}$ the majority Orthodox. Thus, the Orthodox and Catholic Christians settled in Vilnius at the initiative of the grand dukes, as people necessary for the city and the ruler, but the view of these two communities differed.

The different reasons for and circumstances of the emergence of these two Christian communities could have determined the position of the communities themselves, their location in the city, and of course, their different significance in the life of the city. But, there are also common features in the development of the Christian communities, such as the social composition of the communities. First, the craftsmen, merchants, and representatives of the clergy had to come to the city. This shows that the emergence of the Christian communities in the city had an exceptional practical significance. For the grand dukes, Christians were necessary people, who could revive and expand commerce, promote the development of the crafts (for example, jewellery making), introduce new knowledge (masonry construction), and run the grand duke's chancellery. In addition, the Orthodox Christians were also needed as military experts. Thus, the Orthodox and Catholic communities in Vilnius were mainly united by the fact that both were desirable mainly due to a practical contribution to the city's economic and commercial life. As noted by Historian Darius Baronas, during that period the pagan militancy, combined with Christian trades, craftsmanship, and commercial skills, was a good solution for Lithuania. ${ }^{26}$

After settling in a pagan city, the Orthodox and Catholic Christians inevitably performed certain roles in the social - religious - political - economic space and urbanistic structure, e.g., the layout of the city. The Orthodox Christians brought their knowledge of crafts, which is seen especially clearly in jewellery making with the appearance of new metalworking - pressing technology. The peak of the spread of pressing technology was the turn of the $10^{\text {th }}$ century, and the developed forms of pressing technology in Ruthenia date to the $10^{\text {th }}$ century inclusively. The majority of investigators agree with this. ${ }^{27}$ According to Rybakov, pressing technology appeared in the cities of Ruthenia through Byzantine influence. ${ }^{28}$

Pieces of jewellery produced using this method have been discovered in Kernavė, Vilnius, and peripheral burial sites. Although Orthodox influence in

25. Darius Baronas, "Christians in Late Pagan, and Pagans in Early Christian Lithuania: The Fourteenth and Fifteenth Centuries," Lithuanian Historical Studies, no. 19 (2014): 68.

26. Ibid, 59.

27. Галина Корзухина, “О технике тиснения и перегородчатой эмали в древней Руси X-XII вв." Красткие сообщения института истории материальной культурь по. XIII (1946): 45-54; Борис Рыбаков, Ремесло древней Руси (Москва: Наука, 1948); Михаил Каргер, Аревний Киев. Очерки по истории материальной культурь древнерусского города (Москва, Денинград: Академия наук СССР, 1958); Vèlius, Kernavés.

28. Рыбаков, Ремесло, 305. 
mainly noticeable in the everyday life of city residents, ${ }^{29}$ it definitely must have also occurred in the city's political life, especially in the period prior to the official Catholic baptism. Later, after the official Western baptism, the Orthodox Christians, despite some restrictions, remained an important part of the population of Vilnius. In fact, it must be stressed that unlike in the neighbouring states, the arrival of Christians in Lithuanian cities occurred exclusively for economic and political reasons, and not for proselytising. There are no grounds to say that the Orthodox Christians came to Vilnius to proselytise.

\section{The Civitas Ruthenica in Vilnius}

The topographic position of Vilnius is very suitable for division into separate areas. Within each such area, the members of a separate social stratum or religion could develop independently from the others. It is probably no coincidence that the Christian suburbs are laid out especially neatly on different sides of Vilnius, as if "closer to one's kin": the Orthodox in the East, the Catholics in the West, and separating them was a north-south road leading to the castle. The communities were logically founded in such a way that it would be more convenient, accordingly on the road leading east or west. The archaeological material shows some of the former boundaries between the communities. For example, between the eastern Orthodox and the western Catholic parts of the city lay a very clear, long-standing boundary, the strip of land between the territories of north-south road (running from the castle territory to Medininkai and Rūdninkai), the centre of which became the Rotuše (City Hall) and a marketplace from the mid-15 century. Therefore, the hypothesis has been proposed that the growth of the Orthodox Christian suburb was regulated. ${ }^{30}$

Traces of the Orthodox Christian presence can also be seen in the landscape of present-day Vilnius, i.e., several surviving Orthodox churches that have been mentioned since the mid- $15^{\text {th }}$ century ${ }^{31}$ (Figure 3).

29. Alvydas Nikžentaitis, Ikikrikščioniška Lietuvos Visuomene XIII-XIV a. (Vilnius: Vilniaus Universitetas, Vytauto Didžiojo Universitetas, 1999), 32.

30. Gediminas Vaitkevičius, Vilniaus İkūrimas. Vilniaus Sąsiuviniai / 1 (Vilnius: Lietuvos Nacionalinis Muziejus, 2010), 62; Jonaitis, Civitas Rutenica, 31.

31. Jonaitis, "Orthodox," 110. 


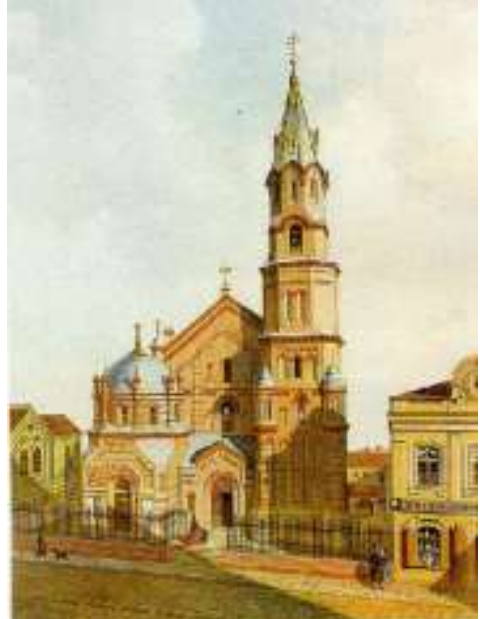

Figure 3. St. Nicolas Church. Lithography Based on a Painting by Ivan Trutnev Source: www.wikiwand.com.

On the basis of later city maps, the location of the Orthodox churches, and the incidence of the cultural layer, the approximate outer boundaries of the Civitas Ruthenica or Ruthenian City as well as their chronology and changes over time $^{32}$ were successfully determined (Figure 4).

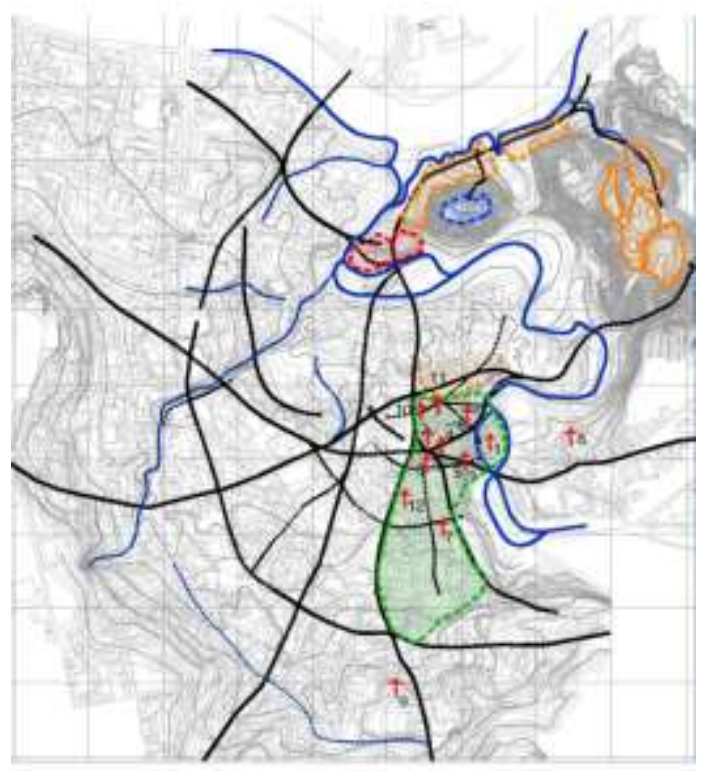

Figure 4. Vilnius Situation in the Middle of the 14 $4^{\text {th }}$ Century. Blue - Citadel; Red Catholic Mission; Green - "Civitas Rutenica" or Ruthenian City; Yellow-Pagans Source: O. Valionienè. Additions by R. Jonaitis.

32. Jonaitis, Civitas Rutenica, 109. 
For example, based on the earliest non-local pottery discovered in this territory, the settlement of the part of the city inhabited by the Orthodox Christians dates to the turn of the $14^{\text {th }}$ century. ${ }^{33}$

The new Orthodox suburb influenced the city's layout: one of the main crossroads of principal roads as well as possibly one of the first marketplaces in Vilnius formed there. ${ }^{34}$ The emergence of the Civitas Ruthenica altered the street network and became a new magnet, towards which the city developed. The oldest known Vilnius cemetery (more later) was also nearby. The territory was distinguished by numerous Orthodox churches, which likewise influenced the city's spaces. It is difficult to say how much influence the architecture of these churches could have had in general on the architecture of the city of Vilnius because the earliest Orthodox churches have not survived. The majority was wooden and only fragments remain of the masonry examples. During this period, the Civitas Ruthenica was the best place to live, being, as it was, near the ruler's castle (roughly $550 \mathrm{~m}$ ), i.e., close to a place of safety, apart from areas inhabited by local pagans, with access to groundwater, and at a main crossroad. The orthodox believers could freely settle here and they were protected by the ruler. The Civitas Ruthenica was a magnet stimulating the building of new roads to and from the suburb as well as transforming the already existing road network. The infrastructure had to match the changing conditions. All of the investigators agree that first placed occupied by the Civitas Ruthenica was at a ford over the River Vilnia.

In the late $14^{\text {th }}$ century the Civitas Ruthenica reached the peak of its expansion at roughly 15 ha (Figure 5).

33. Vaitkevičius, Vilniaus, 62.

34. Jonaitis, Civitas Rutenica, 15. 


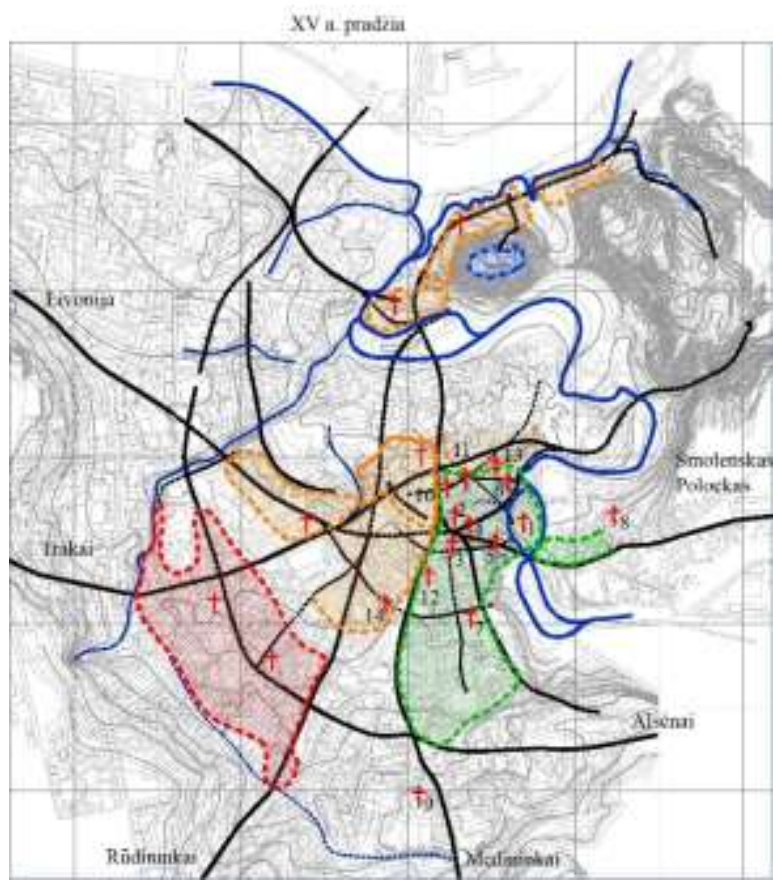

Figure 5. Vilnius Situation in the End of the 14th - The Beginning of the 15th Century. Blue-Citadel; Red-Catholic or German Town; Green - "Civitas Rutenica" or Ruthenian City; Yellow-Pagans.

Source: O. Valionienè. Additions by R. Jonaitis.

It was also well distinguished by twelve Orthodox churches ${ }^{35}$ with another three on the suburb's edge. Such an abundance should come as no surprise. In the authors' opinion, the Orthodox churches of that time were not what people imagine today, i.e., large, masonry structures. In the $14^{\text {th }}$ century, Orthodox churches must have first of all been small and almost without exception wooden, and more reminiscent of a chapel than a church in respect to size. All the more since no archaeological investigation in Vilnius has yet to discover the remains of any of the former Orthodox churches. Only in one instance was a quadrangular masonry building, discovered during an investigation, interpreted as the masonry foundation of the bell tower of the Orthodox Church of St Nicholas. ${ }^{36}$

Although the influence of Orthodox Christians is more noticeable in everyday life, it must have been felt to a greater or lesser degree in the city's public life, especially during the period prior to the official Catholic baptism ${ }^{37}$ when Lithuania was still hesitating over the choice of the Eastern and Western

35. Jonaitis, "Orthodox," 126.

36. Terese Dambrauskaitė, Gorkio-Latako Gatviu Kampas. Istoriniai Tyrimai (Vilnius, 1975).

37. In 1387, most of Lithuania's ruling elite were Catholics, but that elite took into consideration the multi-religious nature of the society (Kiaupiene and Petrauskas, Nauji Horizontai, 211). 
religions. And afterwards the Orthodox Christians, despite some legal restrictions, remained an important part of the society.

A more complete picture of the settlement of the Orthodox Christians in pagan Vilnius was missing only one major bit of evidence concerning their presence in Vilnius, namely their burial site. And so, in 2005, in the east part of present-day Old Town, which is associated with the Civitas Ruthenica, beside a former ford over the River Vilnia, a hitherto unknown archaeological site, an inhumation cemetery displaying Christian funeral features, was discovered ${ }^{38}$ (Figure 6).

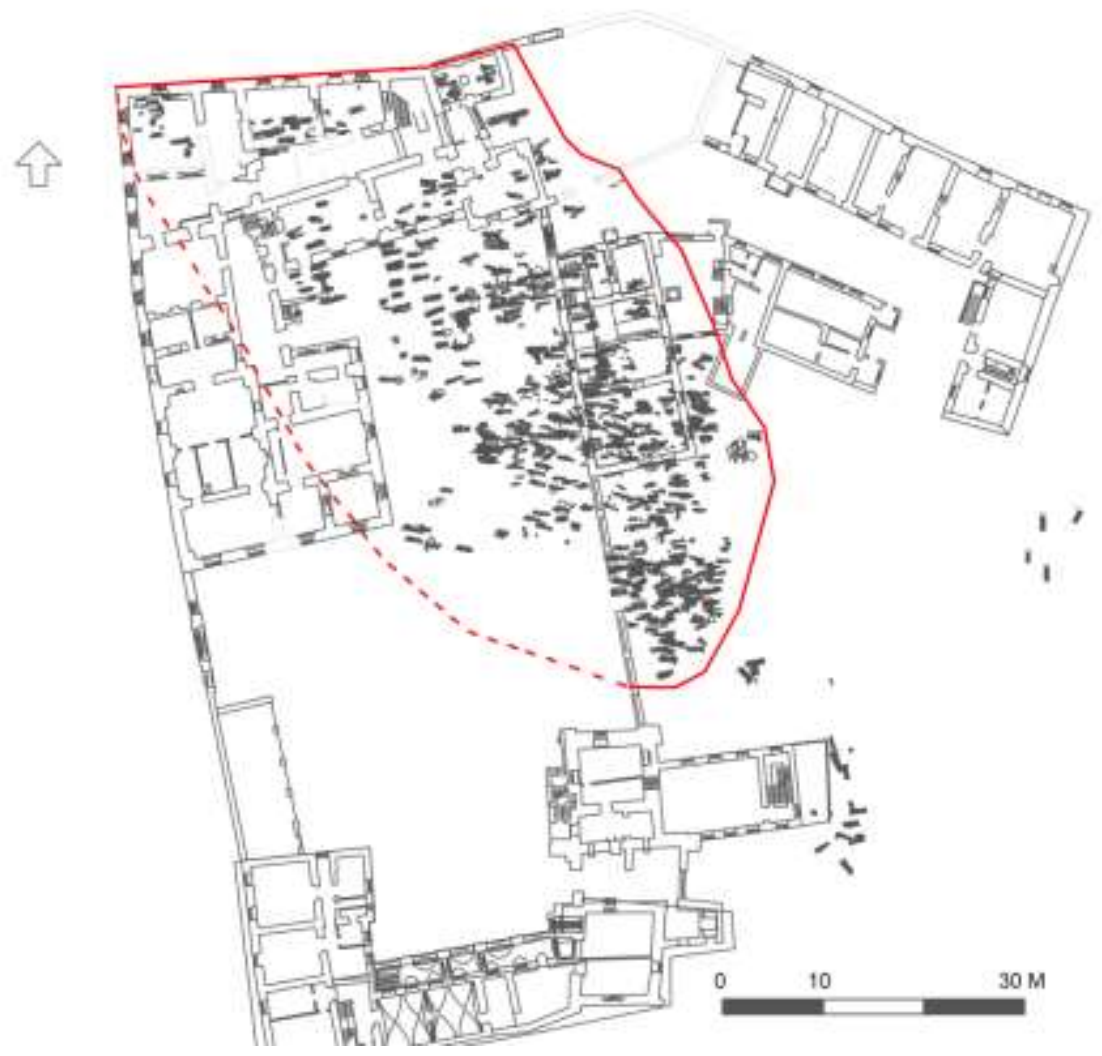

Figure 6. Cemetery in Bokšto Str. 6

Source: I. Kaplūnaitè.

According to the data from the archaeological and interdisciplinary investigations, the cemetery dates to the second half of the $13^{\text {th }}$-early $15^{\text {th }}$ century (see below).

38. Saulius Sarcevičius, Archeologiniu Žvalgomuju Tyrimu Vilniuje, Bokšto g. Nr. 6, ataskaita (Vilnius, 2006). 


\section{The Cemetery on Bokšto Street}

The site at Bokštas St. 6 is in the southeast part of present-day Vilnius Old Town. During the $17^{\text {th }}-$ mid $20^{\text {th }}$ century, the site was home to a city hospital. The excavations began there in 2005 with several test pits that revealed a very rich cultural layer containing human remains. ${ }^{39}$ The excavation, begun in 2006, ended on 31 December $2014^{40}$ and resulted in the excavation of $6000 \mathrm{~m}^{2}$ of the plot's 8600 $\mathrm{m}^{2}$. The $2-7 \mathrm{~m}$ thick cultural layer going back to the $13^{\text {th }}$ century yielded about 20000 potsherds, a huge assemblage of metal, antler, skin, leather, and glass finds, and inhumation burials from the second half of the $13^{\text {th }}$ early $15^{\text {th }}$ centuries (533 undisturbed and perhaps 250 destroyed burials). The research affiliated the burials with Orthodox Christianity. One of the exceptional features of the investigated location is that little construction had occurred within the cemetery's territory over six centuries and so, unlike in much of the rest of Vilnius Old Town, the cultural layer and burials remained well preserved.

All of the burials had been only $50-70 \mathrm{~cm}$ below the former ground's surface. The individuals had been buried supine in wooden coffins (or coffin-like structures). Almost all had an east (foot) - west (head) orientation, with marginal error. The funeral features: an inhumation in a pit grave with the head to the west facing east point to it being a Christian cemetery. In addition, some of the grave goods bear Christian symbols. While the burials belong to Orthodox Christians, these Christians were not necessarily only immigrants; some could have been local converts. A number of burials lay one atop another, i.e., two individuals buried in the same grave, which points to strong family ties. The arrangement of the burials in orderly rows proves that a certain amount of order had been maintained and that some sign had been left on the surface to mark the grave. An age analysis yielded an especially important insight, namely the high mortality of individuals under eighteen.

39. 2005 investigation headed by Sarcevičius (Sarcevičius, Archeologiniu).

40. 2006-2007 and 2009-2011 investigations headed by Jonaitis: Vilniaus Senojo Miesto Vietoje (A1610K1), Sklype Bokšto g. 6, Esamu Pastatu vietose, 2006-2007 m. Vykdytu Archeologijos Tyrimu Ataskaita (I DALIS. Tekstas, Tyrimu Nuotraukos, Priedai) (Vilnius, 2009); Vilniaus Senojo Miesto Vietoje su Priemiesčiais (25504), Ligonines Statiniu Komplekso (1033) ir Vilniaus Miesto Gynybiniu Itvirtinimu Liekanu (39) Teritorijos, Vilniaus m. sav., Vilniaus m. Bokšto g. 6, 2009-2011 Metu Detaliuju Archeologiniu Tyrimu Ataskaita (Vilnius, 2018). And 2012 and 2014 investigations headed by Kaplūnaitè: Vilniaus Senojo Miesto Vietoje su Priemiesčiais (25504), Sklype Bokšto g. 6, 2012 m. Vykdytu Detaliuju Archeologijos Tyrimu. Ataskaita (I DALIS. Tekstas, Tyrimu ir Radiniu Nuotraukos, Priedai) (Vilnius, 2014); Vilniaus Senojo Miesto Vietoje su Priemiesčiais (25504), Ligoninès Statiniu Komplekso (1033) ir Vilniaus Miesto Gynybiniu Itvirtinimu Liekanu (39) Teritorijos, Vilniaus m. sav., Vilniaus m. Bokšto g. 6 2014 Metu Detaliuju Archeologiniu Tyrimu Ataskaita (I TOMAS. Tekstas ir Priedai) (Vilnius, 2016). No investigation was conducted in 2008 or 2013. 
Roughly a quarter of all of the burials were distinguished by more distinct grave pits, which were quadrangles with straight walls and flat bottoms. Some of the pits were trapezoids narrowing towards the foot. Pit length and width varied, the size probably depending on the body shape of the deceased. Coffin traces were also discovered in a quarter of the burials. But these were not coffins like are used now but wooden constructions imitating a coffin, i.e., unjoined planks laid on both sides of the body, above or under it, and/or at the head or foot. Burial in such wooden constructions must have symbolised the separation of the body from the soil surrounding it, a full coffin even more so. In fact, coffins were still fairly rare during the period under discussion. For example, in Novgorod coffins are rarely discovered in late $11^{\text {th }}-14^{\text {th }}$-century burials, the onset of their use on a massive scale having so far not been precisely determined. ${ }^{41}$ Individuals were frequently interred without one in English cities. ${ }^{42}$ Elsewhere in Western Europe they were used only in roughly a third of all burials. They were usually very simple and constructed using dowels. It is interesting that iron nails were discovered in only one burial on Bokšto Street. Everywhere else the planks seem to have not been joined and therefore on the ground's surface such a construction had a stretcher form, as if providing 'handles' (Figure 7).

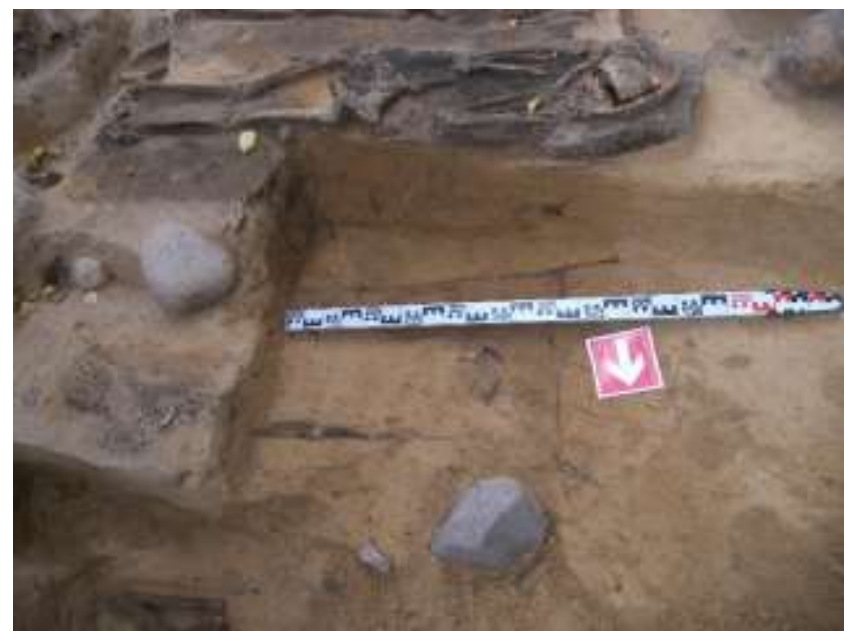

Figure 7. Grave No. 214

Source: R. Jonaitis.

Such constructions were found in the burials of both sexes and various age groups throughout the cemetery. They were often in the burials of various-aged children and even infants. This situation, where the burials of the least members

41. Владислав Соболев, “Древнерусская погребальная культура Новгородской земли: проблемы и особенности формирования," Археологические вести, по. 21, (2015): 360 .

42. John Schofield and Alan Vince, Medieval Towns. The Archaeology of British Towns in Their European Setting (London: Equinoxe, 2003), 187. 
of the community are made in the same way as those for adults is one of the funeral features of Christianity.

An exceptional feature of the cemetery on Bokšto Street was the large number of stones in the grave pits and around the deceased. The greater part of the stones did not form a clear shape and could have found their way into the grave accidentally. The sterile soil at the investigation site contained a very large number of stones and consequently some of them simply were part of the grave pit fill. Overall, 135 burials discovered in the cemetery contained larger stones. It is known that coffins were frequently placed on stones so as to achieve that symbolic separation of the body from the soil..$^{43}$ Keeping in mind that incomplete coffins and wooden planks not secured with nails were used on Bokšto Street, the presence of stones becomes even more logical. Stones could have been used to prop up, support, and put pressure on the planks. In addition, at least some of the stones could have been used as signs marking the gravesite, and would later, after the soil had settled, end up in the grave's fill soil.

Previously, the presence of stones in burials was usually associated in historiography with rituals or magic. But recently their practical purpose has been stressed more, ${ }^{44}$ i.e., stones can be used to support the coffin or body and serve as a sign on the surface. The presence of stones in the cemetery on Bokšto Street was likewise mostly associated by the authors with the construction of the grave pit and of the coffin as well as with the natural geological conditions. In fact, several burials, which looked as if they had been "framed" by stones, were distinguished in the cemetery. Only one burial, no. 226, was completely framed by them (Figure $8)$.

43. Roberta Gilchrist, "Transforming Medieval Beliefs. The Significance of Bodily Resurrection to Medieval Burial Rituals," Death and Changing Rituals. Function and Meaning in Ancient Funerary Practices (2015): 383.

44. Jonaitis, Civitas Rutenica, 54. 


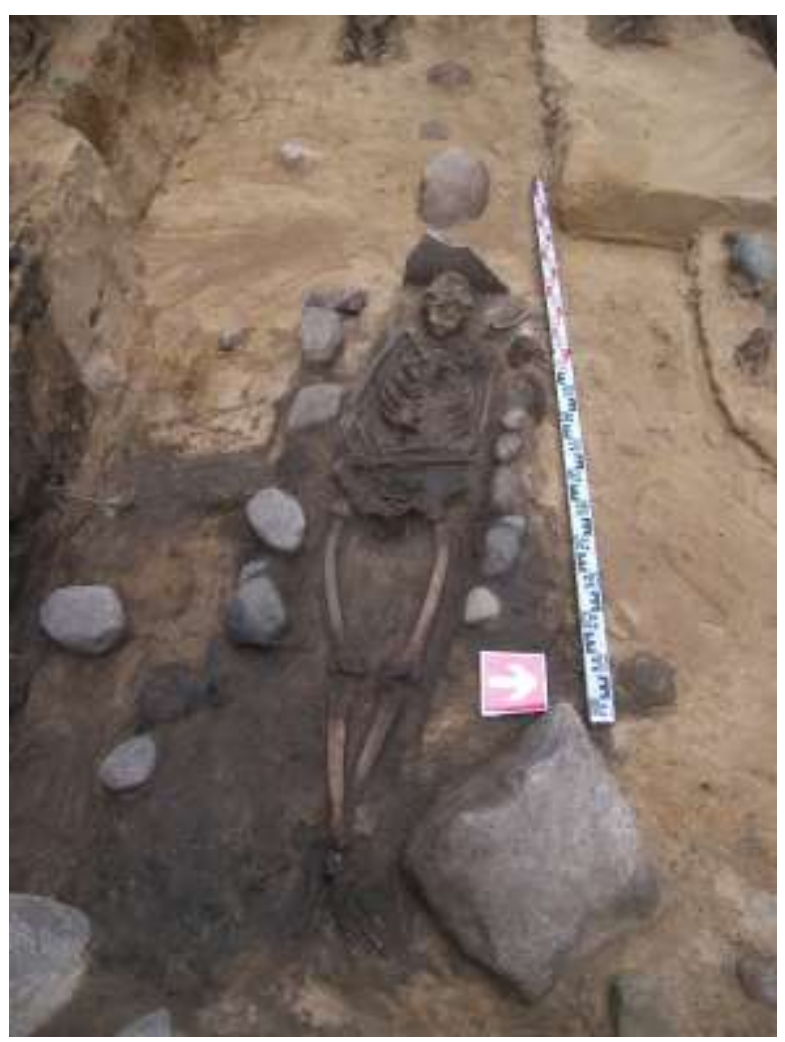

Figure 8. Grave No. 226

Source: R. Jonaitis.

Such framing or the placement of several stones on both sides of the deceased was a frequent phenomena in Medieval burial sites. Usually they are considered part of the grave construction. The tradition of placing stones is also known in Yotvingian lands, in the vicinity of Novgorod (where they are known as 'Жальник, (zhal'nik)) and in the southern territories inhabited by the Slavs. ${ }^{45}$

One of the most distinct and essential Christian funeral features is the eastwest spatial orientation of the burials. After evaluating the orientation of all of the burials discovered in the cemetery on Bokšto Street, it is seen that an east-west burial orientation predominated there, to wit, 395 burials with the deceased interred in a precise or almost precise true east-west orientation (Figure 9).

45. Татьяна Панова, Царство смерти. Погребальный обряд средневековой Руси XIXVI веков (Москва: Радуница, 2004), 68. 


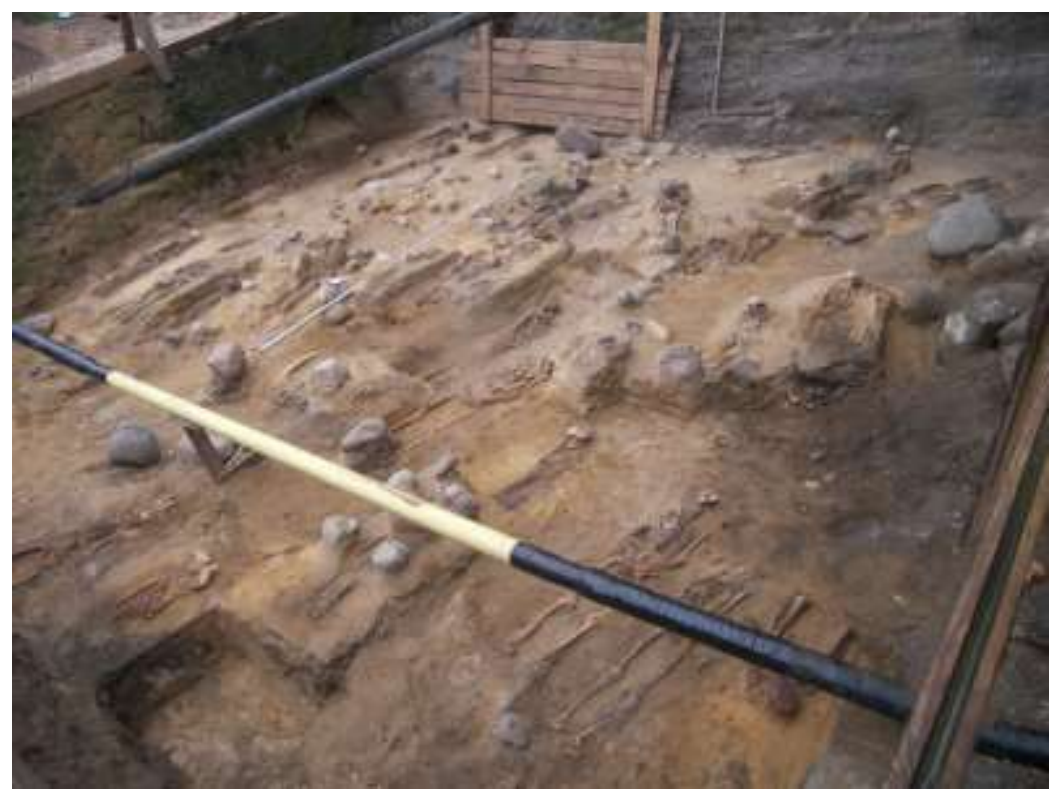

Figure 9. Plot No. 18

Source: R. Jonaitis.

In the other burials the deviation was likewise determined to be fairly small. This could have arisen due to the changing position of the sun at different times of the year. In addition, the topography, i.e., the scarp running down to the River Vilnia and the direction of Išganytojo Street with its bend, could have contributed to the error. The orientation of 15 burials was completely different. But these burials were at a distance from the main part of the cemetery and there are insufficient data so far to establish their connection with it.

Another important Christian funeral element is the position of the arms and legs. The position of both arms was successfully determined in only somewhat less than half of the burials. It is possible to distinguish at least 14 different arm placement variants. But it was seen that in almost half (125) of all of the burials, in which the position of both arms was determined, they were placed symmetrically, i.e., both extended or both on the pelvis, abdomen, or chest or near the neck/ forehead/shoulders.

In Christian inhumation burials the legs are usually extended, but in the cemetery on Bokšto Street instances were encountered where they were turned to one side or the other. This was considered to be the result of the disintegration of the body or its movement during the funeral. Ten instances were encountered where one of the legs was bent slightly at the knee. It is important that pathologies, some being movement related, were established for six of the individuals, for example, healed leg fractures. These perhaps influenced the exceptional position of their legs.

The grave goods discovered in burials were for a long time given an exceptional role. It was thought that finds might reveal religious or ethnic 
affiliation as well as the individual's status. ${ }^{46}$ But post-processual archaeology has rejected this assumption that there is a direct correlation between ethnicity and grave goods. ${ }^{47}$ It is not possible to directly associate finds with a specific ethnic group. In addition, various clothing elements, which can be more closely associated with fashion rather than religion, are frequent grave goods. Nevertheless, by analysing the finds and the entire available context, it is possible to better evaluate the community that left the burial site, the level of its crafts, and its cultural influences.

In talking about the finds discovered in the cemetery on Bokšto Street, it needs to be said that there, like it should be in a Christian burial site, very few grave goods were found, i.e., in 53 of 537 burials, or 10\% of the excavated graves. In addition, they were mostly pieces of jewellery - ornaments, clothing elements, and several crosses. Aside from these, only several other grave goods were found in the burials: symbolic keys, belt fittings, a key for a cylindrical lock, and small knives. The latter were characteristic of only female burials in the cemetery on Bokšto Street. Nevertheless, although the finds were few in number, they, especially the chaplets and rings, were distinguished by their ornateness and uniqueness. The discovered chaplets consisted of sheet metal plates (silver, usually gilt), attached to a cloth or leather band. The plates were quadrangles (square or rectangular), but pentagonal, round, fleur-de-lis shapes were also encountered. Glass (seed) and bone beads were often sewn onto the plates (Figure 10).

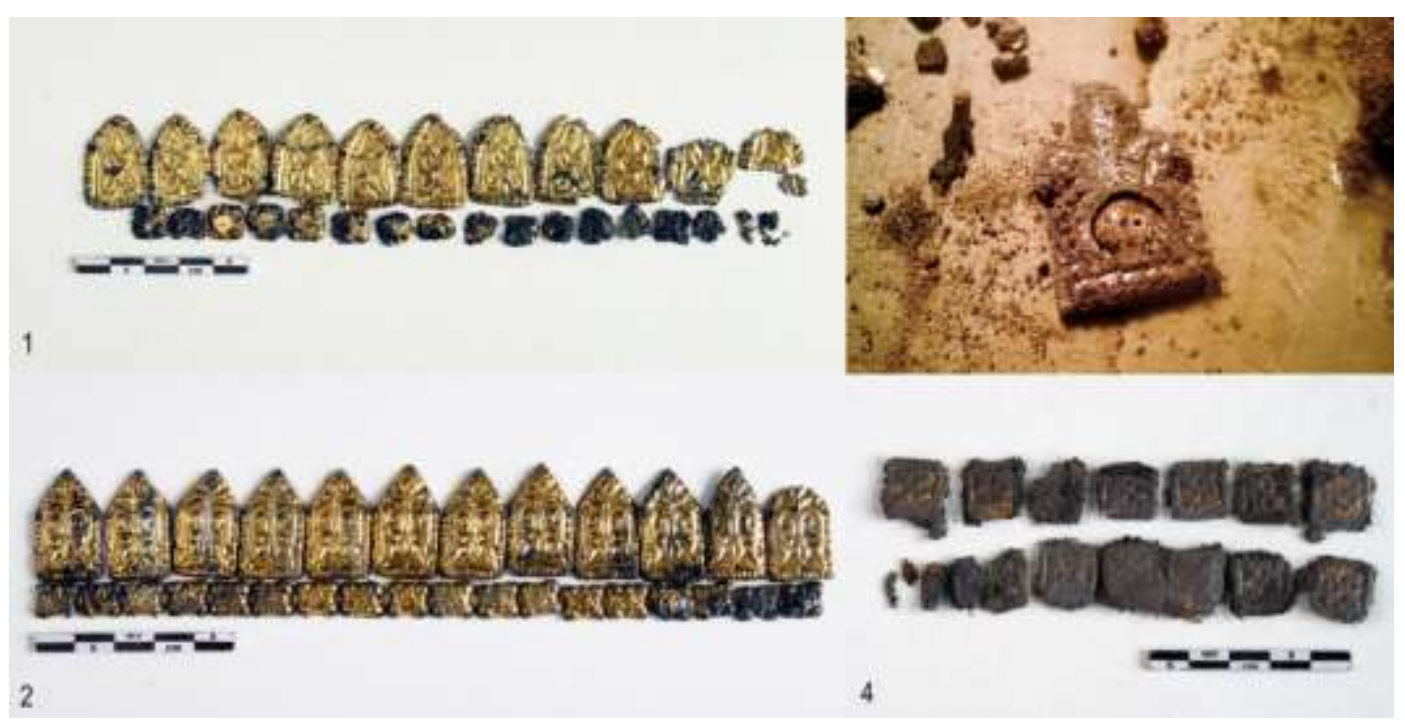

Figure 10. Chaplets. 1 - Grave No. 15; 2 - Grave No. 21; 3 - Grave No. 106; 4 - Grave No. 188.

Source: 1-2, 3 - A. Blažys; 4 - R. Jonaitis.

46. Michael Garcia, "Burial Practices in Early Medieval Britain and Their Interpretation" (2017): 11.

47. Ibid, 12. 
The tradition of wearing chaplets was not known in Lithuania until the $13^{\text {th }}$ century. The assumption was made that both the tradition of manufacturing chaplets and the fashion of wearing them could have arrived in ethnic Lithuanian lands from Galicia-Volhynia together with the first Orthodox Christians. ${ }^{48}$ The emergence of this fashion can be called a cultural phenomenon precisely connected with the arrival of the Orthodox Christians. The first Eastern Christian immigrants brought not only their tradition of wearing chaplets but also the technology for the manufacture of chaplet plates. In summarising the road of chaplets to Lithuania, it is possible to distinguish the following highpoints: chaplet prototypes first appeared in Byzantium, this fashion novelty being transmitted to Kievan Rus' together with Christianity. In the $10^{\text {th }}$ century the technology for pressing metal, which was used in the production of chaplets, first appeared and spread in the lands of Galicia-Volhynia and the fashion of wearing them spread to the neighbouring regions. Against the background of precisely the relationship between Galicia-Volhynia ${ }^{49}$ and Grand Duke Traidenis ${ }^{50}$ of Lithuania, the fashion of wearing chaplets made its way, via lands inhabited by the Yotvingians, to the first two centres of ethnic Lithuania: Kernave and Vilnius.

Another find group, rings, or more precisely, idiosyncratic silver rings with glass stones, is also worthy of more attention (Figure 11).

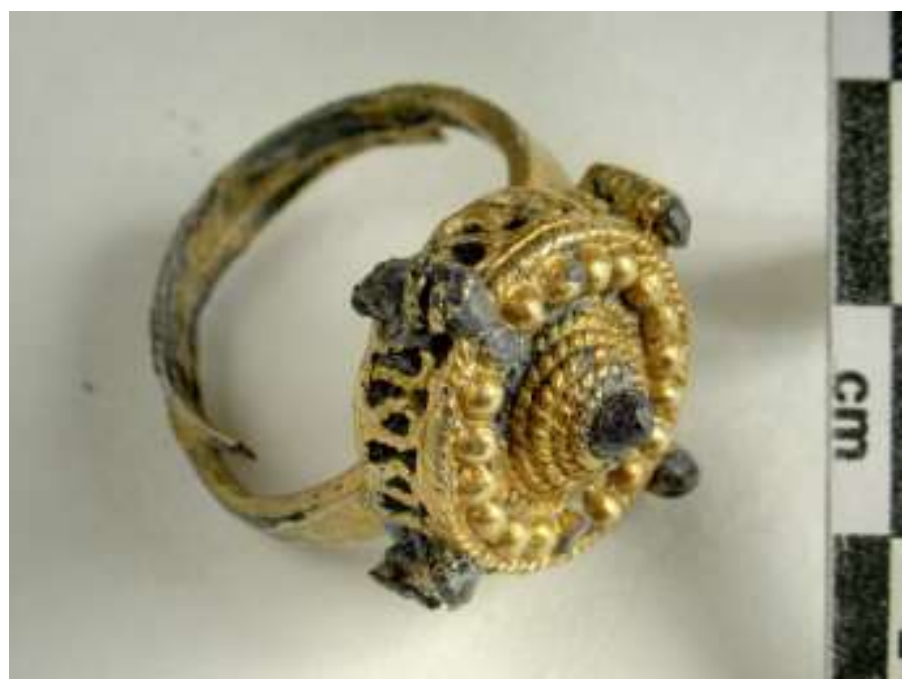

Figure 11. Ring. Grave 21.

Source: A. Blažys.

48. Рітіс Йонайтіс, “Головные венчики как индикатор миграционного пути в XIII-XIV вв. через Киев в Иитву," Ukraina Lithuanica: студї̈ з історії Великого князівства Аитовського. Т. IV: На пошану Миколи Федоровича Котляра з нагоди його 85-річчя (2017): 113.

49. This Galicia-Volhynia direction was already dominating in Ruthenian politics during the reign of Mindaugas. For more, see: Gudavičius, Lietuvos, 48-51.

50. The sister of Vaišvilkas, who escaped to Galicia-Volhynia, can be mentioned here. 
The cemetery on Bokšto Street yielded 40 rings of various types, which can be divided into several groups: rings with a woven upper shank; tapered rings; rings with a glass stone; signet rings; band rings; rings with a hollow gallery; a ring with a disc. Rings with a glass stone, at 6 items, were the third largest ring group in the cemetery on most Bokšto Street. In two burials adult females were interred together with two such rings, one on each hand. These are not a frequent find in urban cemeteries. ${ }^{51}$

The rings with glass stones were definitely the work of local jewellers. No analogues of these rings could be found in the Ruthenian archaeological material. Only one ring of this type is known from the Yotvingian cemeteries..$^{52}$ Ornaments are a reflection of the cultural influences and migration. But at the same time, their presence simply shows the fashion. They are an important and interesting source for research but in evaluating them, one need not give them too much meaning by very simply and directly associating some ornament with a religion or, even worse, with an ethnic group.

Only 6 adult male burials contained grave goods (8 items): rings, belt fittings, purses, and a brooch(?) fragment. This situation is logical. Men wear little jewellery and the other grave goods (weapons and tools) were no longer placed in Christian burials. In addition, tools and weapons are not found at all or are discovered very rarely in urban cemeteries. Weaponry and tools are more a grave good of village communities living on the periphery.

In summarising all of the grave goods discovered in the cemetery on Bokšto Street it is possible to distinguish several of their features, which are connected with place of origin or cultural influence. The majority of the discovered ornaments are characteristic of Ruthenians rather than Lithuanians, but they also have local features, such as the chaplet plates: Ruthenian ornaments are usually made of quadrangular pieces of sheet metal, but in Lithuania pentagonal or pentagonal and quadrangular examples are found. The very decoration of the sheet metal and the arrangement of the designs are different. ${ }^{53}$ In addition, the technology for the manufacture of such sheet metal had come from Kievan Rus' via Galicia-Volhynia. Multi-bead temple ornaments were popular not just in Vodskaia Piatina in the lands of Novgorod; they spread to a significantly wider area, having been found in North Estonia, Latvia, the lands of Pskov, and the upper reaches of the Nemunas (not only in Drahichyn, but also in the stone barrows of ordinary villagers), in the vicinity of Moscow, and in some other

51. Not that many were found in the cemetery on Bokšto Street compared to nearby Kriveikiškis cemetery, where 22 rings with glass stones were discovered: Vèlius, Kernavés, 73.

52. Ala Kviatkovskaja, Jotvingiu Kapinynai Baltarusijoje (XI a. pab.-XVII a.) (Vilnius: Diemedžio Leidykla, 1998), 93.

53. Ona Kuncienè, "XIII-XIV a. Rytų Lietuvos Moterų Galvos Papuošalai," Mokslu Akademijos Darbai, A serija, no. 3 (48) (1974): 70. 
regions. ${ }^{54}$ It is likely that these ornaments were connected with the religious affiliation of the women who wore them. ${ }^{55}$

An analysis of the burials showed that the funeral features of the individuals interred there were very similar, at least those features, which archaeology allows to be revealed. A homogeneous tradition was practiced; at least part of the rituals must have been the same for everyone. In investigating the burials, no differences or any idiosyncratic features characteristic of either sex or any age group were noticed, except, of course, the more numerous presence of ornaments in female burials. The rituals were the same for male and females, adults, adolescents, and children, and even infants and newborns. This is a characteristic Christian funeral feature. In addition, even the richer burials with grave goods did not differ from the other burials in respect to construction. This situation reflects a feature of Christianity where little individuality remains.

The situation of the cemetery on Bokšto Street is fairly unique. Individuals were interred there in accordance with Christian traditions, but in a pagan environment. Vilnius is a city on the border between different religions. This situation also left traces in the funeral traditions. Some funeral aspects could have been affected by fashion and ambient influences. Pagan features could have existed, but no such slight deviation was observed in the case of Bokšto Street, except perhaps the grave goods. But these were few in number, ornaments predominating, and there were no finds, which it would be possible to associate with paganism.

It is possible that not only Orthodox Christian immigrants were interred there but also local converts. The female ornaments and the motifs of their decoration are characteristic of Slavs and have Byzantine roots. But these pieces of jewellery could have been manufactured by local craftsmen. That these were probably Orthodox Christians was decided on the basis of the tradition of wearing chaplets, a tradition that came from Kievan Rus'. In the same way, the technology for manufacturing chaplets arrived from the territories of the Southern Slavs.

\section{Conclusions}

The archaeological material from the cemetery at Bokšto St. 6 represents the settlement of the first Orthodox Christians in Vilnius. The arrival of new people is connected with the backyard phenomenon of the ruler. In the mid-13 ${ }^{\text {th }}$ century,

54. Юрий Десман, “Многобусинные височные кодьца," Новгород и овгородская земля. История и археология, по. 3 (1990): 100.

55. In historiography it has been noted that hoop earrings are an ornament of Ruthenian origin: Kunciene, "XIII-XIV a. Rytu", 73; Мария Седова, Ювелирныле изделия древнего Новгорода (Москва: Наука, 1981), 9; Vèlius, Kernavés, 59. 
Vilnius, as a city, was still being created and the first Orthodox Christians had not formed a separate territorial unit (suburb) in the territory of present-day Vilnius Old Town. The new entity in Vilnius is known in historiography as the Civitas Ruthenica, which began to form during the reigns of Grand Dukes Vytenis and Gediminas, i.e. from the turn of the $14^{\text {th }}$ century. From this time it is possible to talk about Orthodox Christians as a distinctive city community inhabiting a separate territory. This community's base consisted of ordinary city residents, merchants, craftsmen, and priests.

The grand dukes of Lithuania understood the benefits provided by the Christian immigrants for increasing the importance of Vilnius. The settlement of Orthodox Christians was a result of the Eastern policy carried out by the rulers. Vilnius had to be attractive to the Orthodox Christian immigrants in respect to security, economic, and commercial matters. The Orthodox Christians settled in a convenient place to live, which was in part due to the topographic position of this territory: a high ground water level, convenient communication with the ruler's castle, and proximity to the earliest marketplace, which had formed at the intersection of international roads. The Orthodox Christians settled under the aegis of the grand duke of Lithuania. The development of the Civitas Ruthenica was regulated by the ruler. This was an open community; its priests could proclaim the truths of their faith in the city without hindrance. The selection of the location of the Civitas Ruthenica shows that security was not the main criterion. Orthodox churches best marked the territory occupied by the Civitas Ruthenica. In the earliest development stage, the area occupied by the territory of the Civitas Ruthenica was roughly 3 ha, but in the early $15^{\text {th }}$ century, up to 15 ha.

The material from the cemetery at Bokšto St. 6 best represents various aspects of the Civitas Ruthenica community. The cemetery reflects the Orthodox Christian funeral tradition, intertwined with local funeral features. The cemetery at Bokšto St. 6 represents a community of ordinary city residents; no grave goods characteristic of elite burials, e.g., weapons, were discovered there. All of the burials discovered in the cemetery were inhumations, the individuals having been interred supine in a coffin, or a wooden constructions imitating a coffin, that was buried in a grave pit. The main and greatest part of the grave goods consisted of ornaments: various chaplets, earrings, necklaces, bracelets, and various types of rings. Some of the ornaments were characteristic of the Slavs (multi-bead and three-bead temple ornaments); some were of local origin (rings with hollow galleries and glass stones). The large number of ornate chaplets allows one to state that the sheet metal chaplet plates were manufactured locally, but under the influence by Slavic culture. All of the grave goods show a high level of jewellery making skill. Based on the find assemblage the cemetery on Bokšto Street has more features in common with the Slavic lands than with the Balts. But the discovered ornaments should be associated more with the fashion contemporary in the city than with an ethnic or religious affiliation. 
The emergence and growth of the Civitas Ruthenica cannot be disassociated from Vilnius as it became a city. The suburb's golden age should be considered the period of the reign of Grand Duke Algirdas (1345-1377). The systemised data allows an image to be recreated of the Civitas Ruthenica as a unique and, at the same time, not an accidental entity in Vilnius. It allowed the logical and consistent development of this part of the city, which was influenced by the country's political history, economic development, natural situation, and even the everyday needs of the city's residents, to be determined. The cemetery at Bokšto St. 6 yielded diverse data about the special features of the life of Vilnius residents of that time, their view of life after death, and their traditions.

\section{Bibliography}

Eiliuotoji Livonijos Kronika. “Mindaugo Knyga: Istorijos Šaltiniai apie Lietuvos Karaliu..” (Mindaugas' Book: Sources of History About the King of Lithuania) (2005): 197-365.

Baranauskas, Tomas. Lietuvos Valstybés Ištakos. (The Origins of the Lithuanian State). Vilnius: Vaga, 2000.

Baronas, Darius, Artūras Dubonis and Rimvydas Petrauskas. XIII a.-1385 m. Valstybés Iškilimas Tarp Rytu ir Vakaru. Lietuvos Istorija, no. III. (13th Century - 1385 the Rise of the State Between East and West. History of Lithuania, no. III). Vilnius: Baltos Lankos, 2011.

. "Christians in Late Pagan, and Pagans in Early Christian Lithuania: The Fourteenth and Fifteenth Centuries." Lithuanian Historical Studies, no. 19 (2014): 51-81.

Dambrauskaitė, Teresė. Gorkio-Latako Gatviu Kampas. Istoriniai Tyrimai. (Corner of GorkyLatak Street. Historical Research). Historical Essay. Vilnius Regional State Archives, Fund 1019, Inventory 11, File no. 6305. Vilnius, 1975.

Dubonis, Artūras. "Lietuva po karaliaus Mindaugo Mirties: Kova dèl Sosto 1264-1268 m." (Lithuania After the Death of King Mindaugas: The Struggle for the Throne in 12641268). Istorijos akiračiai. Skiriama Profesoriaus, habilituoto daktaro Antano Tylos 75-Mečiui (2004): 65-76.

. Traidenis. Vilnius: Lithuanian Institute of History, 2009.

. "G. Vèlius. Kernavès Miesto Bendruomenė XIII-XIV a." (Ghosts. Kernavè City Community in the 13th - 14th Centuries). Lietuvos Archeologija, no. 35 (2009): 259-264.

Garcia, Michael. "Burial Practices in Early Medieval Britain and Their Interpretation." (2017): 1-28. Retrieved from: https://www.academia.edu/3050844/Burial_Practices _in_Early_Medieval_Britain_and_their_Interpretation [Accessed 5 December 2021.]

Gilchrist, Roberta. "Transforming Medieval Beliefs. The Significance of Bodily Resurrection to Medieval Burial Rituals." Death and Changing Rituals. Function and Meaning in Ancient Funerary Practices (2015): 379-397.

Gudavičius, Edvardas. Lietuvos Istorija nuo Seniausiu Laiku iki 1569 Metu. (History of Lithuania from the Earliest Times to 1569). Vilnius: Mokslas, 1999.

Jonaitis, Rytis. Vilniaus Senojo Miesto Vietoje (A1610K1), Sklype Bokšto g. 6, Esamu Pastatu Vietose, 2006-2007 m. Vykdytu Archeologijos Tyrimu Ataskaita (I DALIS. Tekstas, Tyrimu Nuotraukos, Priedai). (On the Site of Vilnius Old Town (A1610K1), on the Plot of Bokšto str. 6, on the Site of Existing Buildings, 2006-2007. Report on Archaeological 
Research (PART I. Text, Research Photos, Annexes)). Archaeological Report. The Lithuanian Institute of History, Manuscript Section, File no. 4929. Vilnius, 2009.

- "Orthodox Churches in the Civitas Rutenica Area of Vilnius: The Question of Location." Archaeologia Baltica, no. 16. (2011): 110-128.

. Civitas Rutenica Vilniuje XIII-XV a. (Russian State Vilniuje XIII-15 a). Doctoral Thesis. Klaipèda: Klaipėdos Universitetas, 2013.

. Vilniaus senojo miesto vietoje su priemiesčiais (25504), Ligoninès statiniu komplekso (1033) ir Vilniaus miesto gynybiniu itvirtinimu liekanu (39) teritorijos, Vilniaus m. sav., Vilniaus m. Bokšto g. 6, 2009-2011 metu detaliuju archeologiniu tyrimu ataskaita. (Territories of Vilnius Old Town with Suburbs (25504), Territories of the Hospital Building Complex (1033) and Remnants of Vilnius City Defensive Fortifications (39), Vilnius c. sav., Vilnius City Bokšto st. 6, Report on Detailed Archaeological Research 2009-2011). Archaeological Report. The Lithuanian Institute of History, Manuscript Section, File no. 8704. Vilnius, 2018.

Jurginis, Juozas, Vytautas Merkys and Adolfas Tautavičius. Vilniaus Miesto Istorija. Nuo Seniausiu Laiku iki Spalio Revoliucijos. (History of Vilnius City. From Ancient Times to the October Revolution). Vilnius: Mintis, 1968.

Kaplūnaitė, Irma. Vilniaus Senojo Miesto Vietoje su Priemiesčiais (25504), Sklype Bokšto g. 6, 2012 m. Vykdytu Detaliuju Archeologijos Tyrimu Ataskaita (I DALIS. Tekstas, Tyrimu ir Radiniu Nuotraukos, Priedai). (On the Site of Vilnius Old Town with Suburbs (25504), on the plot Bokšto str. 6, 2012 Report on the Detailed Archaeological Research Carried out in 2006 (PART I. Text, Photographs of Research and Finds, Annexes)). Archaeological Report. The Lithuanian Institute of History, Manuscript Section, File no. 6684. Vilnius, 2014.

. Vilniaus Miesto Katalikiškoji Dalis XIV-XVI Amžiaus Pradžioje. (The Catholic Part of Vilnius at the Beginning of the 14th-16th Centuries). Doctoral Thesis. Klaipeda: Klaipedos Universitetas, 2015.

. Vilniaus Senojo Miesto Vietoje su Priemiesčiais (25504), Ligoniness Statiniu Komplekso (1033) ir Vilniaus Miesto Gynybiniu Itvirtinimu Liekanu (39) Teritorijos, Vilniaus m. sav., Vilniaus m. Bokšto g. 62014 metu Detaliuju Archeologiniu Tyrimu Ataskaita (I TOMAS. Tekstas ir Priedai). (Territories of Vilnius Old Town with Suburbs (25504), Territories of the Hospital Building Complex (1033) and Remnants of Vilnius City Defensive Fortifications (39), Vilnius c. sav., Vilnius city Bokšto st. 6 Report on Detailed Archaeological Research in 2014 (VOLUME I. Text and Annexes)). Archaeological Report. The Lithuanian Institute of History, Manuscript Section, File no. 7421. Vilnius, 2016.

Kiaupienè, Jūratė and Rimvydas Petrauskas. Nauji Horizontai: Dinastija, Visuomenè, Valstybè. Lietuvos Didžioji Kunigaikštystè 1386-1529 m. Lietuvos Istorija, no. IV. (New Horizons: Dynasty, Society, State. The Grand Duchy of Lithuania 1386-1529 History of Lithuania, no. IV). Vilnius: Baltos lankos, 2009.

Kuncienė, Ona. "XIII-XIV a. Rytų Lietuvos Moterų Galvos Papuošalai." (13th-14th Centuries Eastern Lithuanian Women's Head Jewellery). Mokslu Akademijos Darbai, A Serija 3 no. 48 (1974): 67-75.

Kurila, Laurynas. "Lietuvių Etninė Riba Rytuose IX-XII a. (2. Rašytinių Šaltinių Duomenys)." (Lithuanian Ethnic Boundary in the East IX-XII c. (2. Data from Written Sources)). Lietuvos Archeologija, no. 28 (2005): 121-132. 
Kviatkovskaja, Ala. Jotvingiu Kapinynai Baltarusijoje (XI a. pab.-XVII a.). (Jotvingian Cemetery in Belarus (Late 11th-17th Century)). Vilnius: Diemedžio leidykla, 1998.

Luchtanas, Aleksiejus and Gintautas Vèlius. "Laidosena Lietuvoje XIII-XIV a." (Broadcast in Lithuania XIII-XIV c). Vidurio Lietuvos Archeologija: Etnokultūriniai Ryšiai (1996): 8088.

Marburgietis, Vygandas. Naujoji Prūsijos Kronika. (New Prussian Chronicle). Vilnius: Vaga, 1999.

Nikžentaitis, Alvydas. Ikikrikščioniška Lietuvos Visuomene XIII-XIV a. (Pre-Christian Lithuanian Society in the 13th-14th Centuries). Habilitation Thesis. Vilnius: Vilniaus Universitetas, Vytauto Didžiojo Universitetas, 1999.

Pašuta, Vladimiras. Lietuvos Valstybes Susidarymas. (Formation of the State of Lithuania). Vilnius: Mintis, 1971.

Rowell, C., Stephen. Iš Viduramžiu ūku Kylanti Lietuva. (Lithuania Rising from Medieval Farms). Vilnius: Baltos lankos, 2001.

Rowell C. Stephen (Ed.) Gedimino Laiškai. Chartularium Lithuaniae res Gestas Magni ducis Gedeminne Illustrans. (Letters from Gediminas. A Chart of Lithuania Illustrating the Achievements of the Great Duke Gedeminne). Vilnius: Vaga, 2003.

Sarcevičius, Saulius. Archeologiniu žvalgomuju tyrimu Vilniuje, Bokšto g. Nr. 6, ataskaita. (Archaeological Research in Vilnius, Bokšto str. No. 6, Report). Archaeological Report. The Lithuanian Institute of History, Manuscript Section, File no. 4535. Vilnius, 2006.

Schofield, John and Alan Vince. Medieval Towns. The Archaeology of British Towns in Their European Setting. London: Equinoxe, 2003.

Vaitkevičius, Gediminas. Vilniaus l̦kūrimas. Vilniaus Sąsiuviniai / 1. (Establishment of Vilnius. Notebooks of Vilnius / 1). Vilnius: Lietuvos Nacionalinis Muziejus, 2010.

Vèlius, Gintautas. Kernaves Miesto Bendruomenè XIII-XIV Amžiuje. (Kernavè Town Community in the 13th-14th Centuries). Vilnius: Vilniaus Universitetas, 2005.

Баронас, Дарюс. “Древнейшие следы пребывания русских в Вильнюсе.” (The Oldest Traces of Russians Staying in Vilnius). Slavistica Vilnensis. Kalbotyra 53, no. 2 (2004): 161-166.

Велюс, Гинтаутас. “Могильник XIII-XIV вв. В Кярнаве (Кривейкишис): этническая принадлежность погребенных)." (Burial Ground of the XIII-XIV Centuries. In Kernave (Kriveikishis): Ethnicity of the Buried)). Археология и история Аитвы и Северо-Запада России в средневековье (2013): 59-79.

Йонайтіс, Рітіс. 2017. “Головные венчики как индикатор миграционного пути в XIIIXIV вв. через Киев в Литву." (Head Corollas as an Indicator of the Migration Route in the XIII-XIV Centuries. via Kiev to Lithuania). Ukraina Lithuanica: cmydiï 3 icmopii Великого князівства Аитовського. Т. IV: На пошану Миколи Федоровича Котляра з нагоди його 85-річчя. (2017): 125-145.

Йонайтис, Ритис and Ирма Каплунайте. “Многокультурный Вильнюс. Сосуществование двух христианских конфессий на раннем этапе развития города." (Multicultural Vilnius. Coexistence of Two Christian Denominations at an Early Stage of the City's Development). Elite oи еgalite. Северная Русь и культурные трансформации в Европе VII-XII вв. (2017): 283-304.

Каргер, Михаил, Константинович. Аревний Киев. Очерки по истории материальной культуры древнерусского города. (Ancient Kiev. Essays on the History of the Material 
Culture of the Ancient Russian City). Volume 1. Москва, Ленинград: Академия наук СССР, 1958.

Корзухина, Галина, Фёдоровна. “О технике тиснения и перегородчатой эмали в древней Руси X-XII вв.“ (On the Technique of Embossing and Cloisonné Enamel in Ancient Rus X-XII Centuries). Красткие сообщения института истории материальной культурь по. ХІІІ (1946): 45-54.

Лесман, Юрий, Михайлович. “Многобусинные височные кольца." (Multi-Bead Temporal Rings). Новгород и овгородская земля. История и археология nо. 3 (1990): 99101.

Мусин, Евгеньевич. Milites Christi древней Руси. Воинскал культура русского средневековья в контексте религиозного менталитета. (Milites Christi of Ancient Russia. Military Culture of the Russian Middle Ages in the Context of Religious Mentality) (Militaria Antiqua no. VIII.). Санкт-Петербург: Петербургское востоковедение, 2005.

Панова, Татьяна, Дмитриевна. Царство смерти. Погребальный обряд средневековой Руси XI-XVI веков. (The Kingdom of Death. Funeral Rite of Medieval Russia XI-XVI Centuries). Москва: Радуница, 2004.

Рыбаков, Борис, Александрович. Ремесло древней Руси. (The Craft of Ancient Russia). Москва: Наука, 1948.

Седова, Мария, Владимировна. Ювелирнъе изделия древнего Новгорода. (Jewelry of Ancient Novgorod). Москва: Наука, 1981.

Соболев, Владислав. “Древнерусская погребальная культура Новгородской земли: проблемы и особенности формирования." (Old Russian Funerary Culture of the Novgorod Land: Problems and Features of Formation). Археологические вести, по. 21 (2015): 352-367. 
